\title{
Maspin is a deoxycholate-inducible, anti-apoptotic stress-response protein differentially expressed during colon carcinogenesis
}

This article was published in the following Dove Press journal:

Clinical and Experimental Gastroenterology

30 September 2011

Number of times this article has been viewed

\author{
Claire M Payne ${ }^{1,2}$ \\ Hana Holubec' \\ Cheray Crowley-Skillicorn' \\ Huy Nguyen' \\ Harris Bernstein' \\ George Wilcox ${ }^{3}$ \\ Carol Bernstein' \\ 'Department of Cellular and \\ Molecular Medicine, College of \\ Medicine, University of Arizona \\ ${ }^{2}$ Biomedical Diagnostics and Research, \\ Inc, ${ }^{3}$ Tucson Medical Center, \\ Pathology, Tucson, AZ, USA
}

\begin{abstract}
Increased maspin expression in the colon is related to colon cancer risk and patient survival. Maspin is induced by the hydrophobic bile acid, deoxycholate (DOC), which is an endogenous carcinogen and inducer of oxidative stress and DNA damage in the colon. Persistent exposure of colon epithelial cells, in vitro, to high physiologic levels of DOC results in increased constitutive levels of maspin protein expression associated with the development of apoptosis resistance. When an apoptosis-resistant colon epithelial cell line (HCT-116RC) developed in the authors' laboratory was treated with a maspin-specific siRNA probe, there was a statistically significant increase in apoptosis compared to treatment with an siRNA control probe. These results indicate, for the first time, that maspin is an anti-apoptotic protein in the colon. Immunohistochemical evaluation of maspin expression in human colonic epithelial cells during sporadic colon carcinogenesis (131 human tissues evaluated) indicated a statistically significant increase in maspin protein expression beginning at the polyp stage of carcinogenesis. There was no statistically significant difference in maspin expression between hyperplastic/adenomatous polyps and colonic adenocarcinomas. The absence of "field defects" in the non-neoplastic colonic mucosa of patients with colonic neoplasia indicates that maspin may drive the growth of tumors, in part, through its anti-apoptotic function.
\end{abstract}

Keywords: maspin, anti-apoptotic, bile acid-inducible, immunohistochemistry, colon cancer

\section{Introduction}

Colon carcinogenesis is associated with a high-fat diet $^{1}$ and such a diet results in increased concentrations of endogenous bile acids in the gut. ${ }^{2-4}$ Although numerous bile acids are released from the gallbladder into the small intestine, only the hydrophobic bile acids are particularly damaging to cells. ${ }^{1}$ The hydrophobic bile acids, deoxycholic acid, and lithocholic acid, resulting from bacterial metabolism, are the predominant bile acids found in the human colon. Thus, in previous work, the authors explored the effects of exposure of cells of colonic origin to high pathophysiologic concentrations of deoxycholate (DOC). It was shown that repeatedly exposing HCT-116 colon epithelial cells to increasing concentrations of DOC over months resulted in the development of cells with apoptosis resistance, ${ }^{5}$ a hallmark of cancer. ${ }^{6,7}$ Apoptosis resistance during colon carcinogenesis is a major process associated with the survival of cells with genomic instability. ${ }^{8-11}$ 2D-gel electrophoresis/matrix-assisted laser desorption/ionization (MALDI)-mass spectroscopy of these apoptosis-resistant cells indicated, unexpectedly, that maspin was one of the proteins that was substantially upregulated. ${ }^{5}$

Maspin is a $42 \mathrm{kDa}$ protein with high sequence homology to members of the serpin peptidase inhibitor family of proteins. ${ }^{12,13}$ Early experimental results with
Correspondence: Claire M Payne Biomedical Diagnostics and Research Inc, 625 South Plumer Ave, Tucson,

Arizona 85719, USA

$\mathrm{Tel}+\mid \mathbf{5 2 0} 8850662$

Fax +I 5202968223

Email bmdiagnostics@cox.net 
maspin in mammary tissue indicated that it acts as a tumor suppressor. ${ }^{14,15}$ However, maspin does not undergo the $\mathrm{S}$ (stressed) to R (relaxed) conformational transition that characterizes active serpins. ${ }^{16,17}$ Thus, the mechanisms by which it exerts its tumor suppressor activity have been actively sought. One of the mechanisms proposed to explain the tumorsuppressive functions of maspin in noncolon-derived cells is that it sensitizes cells to apoptosis, ${ }^{18-25}$ thereby preventing the clonal expansion of preneoplastic cells with DNA damage. In contrast to mammary tissue, maspin expression in colon epithelial tissue appears to be related to increased colon cancer risk and reduced patient survival. ${ }^{26-31}$ High maspin expression is associated with neoplastic transformation and high tumor grade.

It was determined, using small interfering RNA (siRNA) technology, that maspin is an anti-apoptotic protein in colon epithelial cells, which can explain the association of increased maspin expression with increased risk of colon carcinogenesis. Human colonic tissues were screened, using immunohistochemical analysis, to determine if maspin was differentially expressed during colon carcinogenesis. Maspin's first increased expression occurred at the hyperplastic/adenomatous polyp stage of colon tumorigenesis. No evidence of "field defects" with respect to maspin expression was observed in the non-neoplastic mucosa of patients with polyps or adenocarcinomas. The role of maspin as a "double-edged sword" during colon carcinogenesis is discussed in the light of these new findings.

\section{Materials and methods SiRNA methodology}

Potential siRNA probes were identified by Dr Seth Ririe, Senior Technical Service Scientist (QIAGEN, Inc, Valencia, CA) by scanning the mRNA nucleotide sequence for human maspin (GenBank Accession \#NM_002639) using QIAGEN Software. Three siRNA probes were selected to have the highest potential for success based on siRNA design (QIAGEN, Inc). A BLAST (Basic Local Alignment Search Tool [designed by scientists at the NIH]) search was performed on these three oligonucleotide sequences, and the 19-mer sequence that was very specific with homology only to maspin mRNA (3'-dTdTGUCACACUUGCUGGUCUGG-5') was chosen for the siRNA experiments. This sequence started at nucleotide \#528 of the human maspin mRNA sequence (GenBank Accession \#NM_002639). An siRNA control probe was provided by QIAGEN that does not target any known human gene. HCT-116RC colon epithelial cells were selected for the siRNA experiments, as it was one of the three resistant cell lines that was developed in the authors' laboratory after persistent exposure of HCT-116 parental cells to increasing concentrations of the hydrophobic bile acid, DOC, for a period of $\sim 40$ weeks. ${ }^{5}$ This cell line became stably resistant to apoptosis induced by $0.5 \mathrm{mM}$ DOC and maintained a high level of maspin expression (sodium DOC was obtained from Sigma Aldrich [St Louis, MO]). The stability of this cell line as to apoptosis resistance and high maspin expression was ensured in the present siRNA experiments by including $0.5 \mathrm{mM}$ DOC as a negative control. The HCT-116RC cells were plated in 24-well Falcon polystyrene tissue culture dishes (Fisher Scientific, Pittsburgh, $\mathrm{PA})$ at a concentration of $1 \times 10^{5}$ cells $/ \mathrm{mL}$, and treated with either $0.8 \mu \mathrm{g}$ maspin-specific siRNA probe, $0.8 \mu \mathrm{g}$ siRNA control probe, $0.5 \mathrm{mM}$ DOC, or control media for 24 hours. (SiRNA treatments for 48 hours decreased cell viability, as determined using trypan blue exclusion.) All wells contained the TransMessenger Transfection Reagent (TTR) from QIAGEN. The ratio of siRNA to TTR was 1:5 ( $\mu \mathrm{g}: \mu \mathrm{L})$. A total of ten experiments were used to analyze for the induction of apoptosis by the siRNA probes.

\section{Assessment of apoptosis in SiRNA experiments}

Cytospins were prepared of all experimental groups: (1) untreated control or treated with (2) DOC, (3) siRNA, or (4) control siRNA, and stained with Giemsa stain. A total of ten siRNA experiments were included to assess statistical significance. One hundred cells were counted from each prepared slide and the percentage of apoptosis assessed using standard morphologic criteria. ${ }^{8,32}$

Briefly, apoptotic cells can be identified by bright-field microscopy using the following criteria in various stages of the apoptotic process: condensation of the chromatin (deep purple to black stain intensity), fragmentation of the nucleus into round discrete chromatin masses, increase in cytoplasmic blebbing, and the formation of apoptotic bodies.

\section{Western blot analyses}

Western blot procedures were performed as previously described. ${ }^{33,34}$ Cells were grown in $20 \times 50 \mathrm{~mm}$ Falcon polystyrene tissue culture dishes. Cultures treated with DOC or siRNA probes or cells incubated in control media were disrupted in lysis buffer (50 mM Tris pH 8, 5 mM EDTA, $150 \mathrm{mM} \mathrm{NaCl}, 0.5 \% \mathrm{NP}-40)$ supplemented with $1 \mathrm{mM}$ phenylmethylsulfonyl fluoride (PMSF), leupeptin $(1 \mu \mathrm{g} / \mathrm{mL})$, and aprotinin $(0.01 \mathrm{U} / \mathrm{mL})$. Cell lysates were prepared at a concentration of $2 \mu \mathrm{g} / \mu \mathrm{L}$ of protein and a total of $20 \mu \mathrm{g}$ of 
protein was added to each well of a $15 \%$ Criterion Tris- $\mathrm{HCl}$ gel (Bio-Rad, Hercules, CA) for size fractionation by electrophoresis. The proteins were blotted onto Immobilon-P polyvinylidene fluoride (PVDF) transfer membranes (Millipore, Bedford, MA). The membranes were incubated with mouse antihuman maspin antibody (catalog \#554292; BD Biosciences Pharmingen, San Jose, CA) at a dilution of 1:1000. The membranes were then incubated with goat antimouse secondary antibodies conjugated to horseradish peroxidase (Thermo Scientific, Rockford, IL). Antibody complexes were detected using the SuperSignal West Pico chemiluminescence detection system (Thermo Scientific). Finally, the membranes were stained for 20 minutes with Brilliant Blue G dye (Sigma-Aldrich, St Louis, MO) to confirm equal protein loading, as previously described. ${ }^{33,34}$ Brilliant Blue $G$ dye was chosen to stain the membranes rather than a specific protein as a loading control since Brilliant Blue staining evaluates numerous bands found in the entire ge $^{33,34}$ whereas the evaluation of a specific protein can be misleading. This approach is based on work published from the authors' laboratory using GAPDH and G3PD, ${ }^{35}$ and the results of Qi and $\mathrm{Sit}^{36}$ who screened 22 housekeeping genes and found a large number to be modulated by various experimental conditions. In addition, the cytoskeletal protein, $\beta$-actin, has been reported not to be a reliable loading control in Western blot analysis. ${ }^{37}$ Even F-actin has been reported to be experimentally modulated as evidenced by the decomposition of F-actin in apoptosis experiments. ${ }^{38}$

The Western blot experiments were repeated at least three times; in the repeats, separate cultures were treated and cell lysates were separately prepared. The band intensities after siRNA and DOC treatments were then compared with control cells (no siRNA, no DOC) using automated densitometry (Image-Pro software package, v 5.1.1.38; Media Cybernetics, Silver Spring, MD), and the values normalized to control values. Two replicates from each lysate were also run to ensure technical reproducibility.

\section{Procurement of human colon tissues}

A total of 131 tissue samples was procured for this study with informed consent according to procedures approved by the institutional review boards at the University of Arizona (supervises human subject studies at University Medical Center [UMC] and the Southern Arizona Veterans Affairs Health Care System [SAVAHCS]) and the Tucson Medical Center (TMC). All tissue samples $(n=106)$ from colon resections (16 patients [two normal, two diverticulitis, seven with sporadic adenocarcinomas, four with large adenomas, one with ulcerative colitis/adenocarcinoma]) were obtained in the operating room at UMC. In the resected colon segment, samples of the non-neoplastic mucosa were taken adjacent to the tumor on the proximal and distal sides (P0, D0), $2 \mathrm{~cm}$ away on the proximal and distal side (P2, D2) and near the surgical margins (PMAX, DMAX). These tissue samples were fixed immediately in formalin by $\mathrm{CMP}$ and $\mathrm{HH}$, as previously described. ${ }^{39-41}$ All colonoscopy tissue samples $(\mathrm{n}=10)$ from five patients without colonic disease were obtained at $\mathrm{UMC}$ and at SAVAHCS under the direct supervision of CB and fixed immediately in formalin, as previously described. ${ }^{42}$ Tissue samples from archived biopsies of polyps/adenomas ( $\mathrm{n}=8$, including two hyperplastic polyps, six adenomatous polyps), and colon cancers $(n=7)$ were obtained from TMC and selected for the present study by GW.

\section{Immunohistochemical procedures}

Four micron sections of each paraffin block were prepared, immersed in xylene and rehydrated through a series of ethanols. Antigen retrieval was achieved using Vector AR (Vector Laboratories, Burlingame, CA) in a microwave and endogenous peroxidase blocked with $30 \% \mathrm{H}_{2} \mathrm{O}_{2}$ (SigmaAldrich). Background Sniper from a Mach 3 (Biocare Medical, Concord, CA) kit was applied followed by mouse antihuman maspin antibody (catalog \#554292; BD Biosciences Pharmingen), the secondary antibody (polyclonal rabbit antimouse biotinylated antibody [catalog \#E0413; DAKO, Glostrup, Denmark]), and then by Vector PK6100 (Vectastain ABC kit; Vector Laboratories, Burlingame, CA) and 3,3'-diaminobenzidine (Sigma-Aldrich). Slides were counterstained with freshly filtered hematoxylin, dehydrated through a graded series of ethanols, immersed in xylene, and mounted using Cytoseal Mounting Medium (VWR, Tempe, AZ), as previously described..$^{42,43}$

\section{Scoring of immunohistochemical results}

The intensity of the maspin stain (light to dark brown color) and extent of the tissue expressing the maspin stain were taken into consideration using the immunohistochemical procedures described above. Slides were scored for maspin expression using a scale of 0 to +4.0 . Since maspin expression was shown to be high in ulcerative colitis (UC), ${ }^{28}$ a case of UC from the authors' archived colon tissue bank was used as a positive control for this study. The associated adenocarcinoma from this UC case was strongly positive and received a score of +4 . A more complete description of this positive control (with images) is described in Results. Slides that received no primary antibody served as the immunocontrol 
in each experimental run, and consistently had a score of zero (no brown stain). No tissues in the study that received the maspin antibody had a score of zero. Tissues with a blush of maspin staining were given a score of 0.5 . The rest of the tissues were given a score of $1,2,3$ or 4 , relative to the strongly positive UC control tissues (ranged from 2 to 4). Epithelial cells near lymphoid follicles often expressed increased maspin. This immunostaining pattern was observed in both control samples and in the non-neoplastic mucosa of patients with colonic tumors; such immunostaining was not evaluated in the scoring of the tissues.

\section{Statistical analyses}

Individual densitometric scan values from experimental groups in Western blots, apoptosis percentages from siRNA experiments, and maspin immunostaining scores from human tissue groups were entered into spreadsheets using Microsoft Office Excel 2007 (Microsoft, Redmond, WA) software. The following parameters were assessed for each experimental group: average, standard deviation, and standard error of the mean. Differences in mean values between experimental groups were considered statistically significant at the $95 \%$ confidence level using Student's $t$-test. Actual $P$ values are reported in the study.

\section{Photography}

Digital images were obtained with $4 \times$ and $20 \times$ Nikon objectives using a Nikon Eclipse E400 (Nikon, Tokyo, Japan) bright-field microscope equipped with a Moticam 2300 (Motic $^{\circledR}$, Xiamen, China) 3.0 megapixel camera using Motic Images Plus (v 2.0; Motic) digital imaging software.

\section{Results}

\section{Maspin proven to be an anti-apoptotic protein in colon epithelial cells in vitro based on siRNA strategies}

To determine if the reduction in maspin induced apoptosis, the apoptosis-resistant HCT-116RC cells were exposed to a maspin-specific antisense 19-mer oligonucleotide probe (3'-dTdTGUCACACUUGCUGGUCUGG-5'), and to a control siRNA probe for 24 hours and compared with control cells (no siRNA, no DOC) and cells treated with $0.5 \mathrm{mM}$ DOC. (The control cells received only the TransMessenger Transfection Reagent (TTR) without any siRNA probe or DOC; the DOC-treated cells in TTR media served as a control for the stability of the resistant state of the cells.) Treatment of cells with the maspin-specific siRNA probe resulted in a statistically significant increase in apoptosis when compared with: (1) control cells $\left(P=3.29 \times 10^{-5}\right),(2)$ cells treated with DOC $\left(P=9.58 \times 10^{-5}\right)$, and $(3)$ cells treated with a control siRNA probe $\left(P=4.57 \times 10^{-3}\right)$ (Figure 1$)$. The control siRNA probe showed a statistically significant increase in apoptosis when compared with control cells $\left(P=9.05 \times 10^{-3}\right)$ and DOC-treated cells $\left(P=9.14 \times 10^{-3}\right)$. DOC treatment did not show an increase in apoptosis compared with control cells $(P=0.173)$.

To ensure that the maspin siRNA knocked down the protein expression level of the $42 \mathrm{kDa}$ maspin protein, the same treatment of cells as above was performed, and Western blots from each treatment group were probed with a monoclonal antibody for maspin (Figure 2A). A densitometric analysis (Figure 2B) indicated that treatment of cells with the maspinspecific siRNA resulted in a significant $\left(P=7.8 \times 10^{-3}\right)$ reduction in maspin protein expression compared with untreated control cells. There was no significant reduction in maspin expression using the control siRNA $(P=0.272)$ or the DOC treatment $(P=0.437)$.

In conclusion, the use of a specific maspin siRNA probe resulted in an approximately $20 \%$ reduction in maspin protein levels, which had a significant effect on the induction of apoptosis. These findings indicate that maspin was responsible, in part, for the observed resistance of the HCT116 cells.

\section{Immunohistochemical evaluation of a case of UC as a positive control for maspin expression}

Since maspin expression is reported to be high in the nonneoplastic mucosa and associated adenocarcinomas from patients with inflammatory bowel disease, ${ }^{28}$ a case of UC from the authors' tissue archives was included as a positive control for the present immunohistochemical studies on sporadic colon cancers. Tissue from the cancer and 13 regions of the non-neoplastic colonic mucosa (PMAX, P3, P2, P0, D0, D2, D3, D4, D5, D6, D7, D8, D9) was immunostained for maspin and the intensity of expression scored on a scale of 0 to +4.0 . Representative bright-field microscopic images displaying maspin expression are shown in Figure 3. The adenocarcinoma displayed the highest expression of maspin (score of +4) (see Figure 3, Panel F), with abundant nuclear maspin staining in addition to cytoplasmic staining. Twelve of the non-neoplastic tissue samples received a score of +3 and one received a score of +2 . All 130 tissue samples from patients with polyps/sporadic colon cancer and from patients with no evidence of colonic neoplasia in the present study were compared with this positive control. 


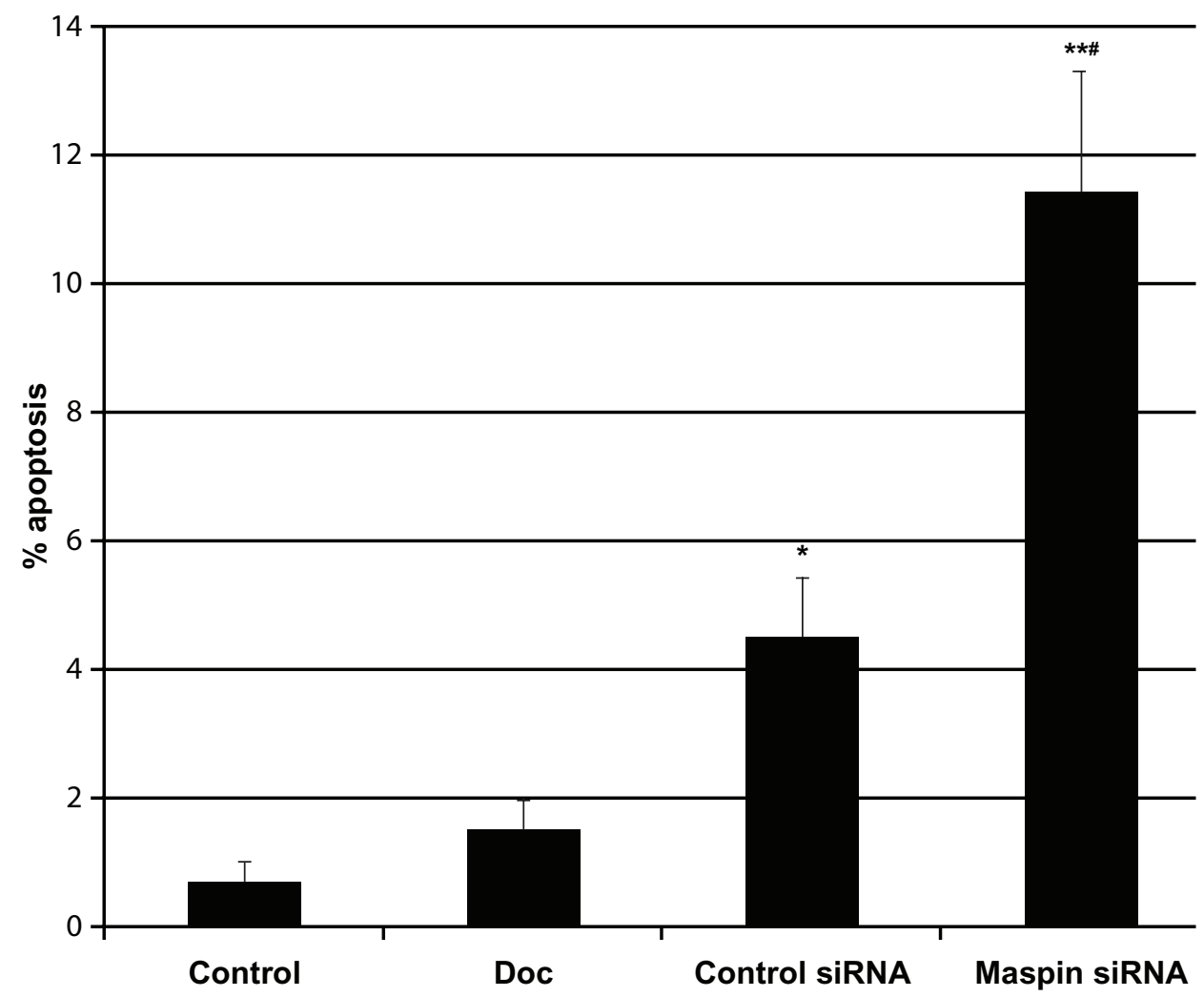

Figure I HCT-II6RC cells treated with either control media, $0.5 \mathrm{mM}$ DOC (deoxycholate), control siRNA, or maspin-specific siRNA for 24 hours and the percentage of apoptosis \pm SEM determined for each experimental group. The single asterisk indicates statistically significant differences compared to untreated cells in control media. Treatment of cells with $0.5 \mathrm{mM} \mathrm{DOC} \mathrm{served} \mathrm{as} \mathrm{a} \mathrm{control} \mathrm{to} \mathrm{ensure} \mathrm{that} \mathrm{the} \mathrm{cells} \mathrm{had} \mathrm{maintained} \mathrm{their} \mathrm{apoptosis} \mathrm{resistance} \mathrm{to} \mathrm{the} \mathrm{same} \mathrm{apoptosis-inducing} \mathrm{agent} \mathrm{that} \mathrm{was} \mathrm{used}$ to develop the resistant cells over $\sim 40$ weeks of persistent exposure. There was no significant increase in the \% apoptosis after treatment of cells with 0.5 mM DOC.

Notes: *Control siRNA treatment resulted in significantly more apoptosis than control cells and DOC-treated cells; **Maspin siRNA treatment resulted in significantly more apoptosis than both control cells and DOC-treated cells; $\#$ apoptosis induced by the specific maspin siRNA probe was significantly higher than that produced by the siRNA control. Abbreviations: siRNA, small interfering RNA; SEM, standard error of the mean; DOC, deoxycholate.

\section{Immunohistochemical evaluation of maspin expression in human tissues during colon cancer progression}

Progression to colon cancer proceeds by means of numerous changes in the colonic mucosa, progressing from normal tissue to "field defects" in the non-neoplastic flat mucosa, to hyperplastic polyps, to adenomatous polyps (adenomas), and, ultimately, to colon cancer. A total of 131 representative tissues from the authors' colon tissue banks was screened and the intensity and pattern of maspin expression at each of these stages was compared.

The colonic mucosa from patients with no evidence of colonic neoplasia exhibits a low expression of maspin

Multiple tissue samples of colonic mucosa were obtained from patients without colonic neoplasia. These tissue samples were from resected colon segments obtained during surgery and from biopsies obtained during colonoscopy. Two patients had a recurrent sarcoma removed that was external to the colon wall. To prevent further possible recurrences of the sarcoma, the surrounding tissues, including a segment of colon, were removed. Neither patient received radiation or chemotherapy prior. Two patients had diverticulitis that required the removal of the involved colon segment. Five patients with no evidence of colonic lesions had two biopsies of the colonic mucosa taken during routine colonoscopy. An immunohistochemical evaluation of maspin expression indicated low expression of maspin (score of 0.5 or 1 ) in these 35 tissue samples (Table 1 ). There was some variability in the pattern of maspin expression (Figure 4), but all colonic tissues showed some focal or diffuse maspin expression in the cytoplasm of the epithelial cells. The low overall expression in the colonic crypts is shown in Figure 4A, $\mathrm{D}$, and $\mathrm{E}$. The low overall staining predominantly at the top of the crypts is shown in Figure $4 \mathrm{C}$ and F. Focal distinct staining in individual cells of the crypts is shown in Figure 4B. There was no statistical difference $(P=0.91)$ (Table 1$)$ in maspin expression between the colonoscopy specimens (Figure $4 \mathrm{~A}$ and $\mathrm{B}$ ) and the non-neoplastic tissue samples from the colon resections of patients with no colonic neoplasia (Figure 4C-F). 


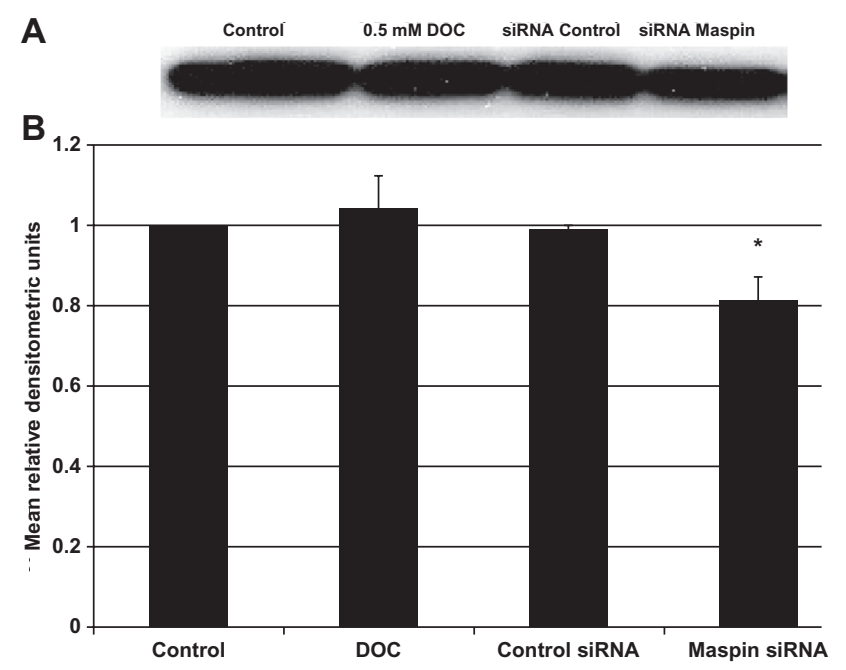

Figure 2 (A) Western blots of maspin expression from HCT- I I6RC cells treated with $0.5 \mathrm{mM}$ DOC, siRNA control probe, or siRNA maspin probe for 24 hours. (B) Relative protein expression levels were obtained using densitometry. DOC treatment was used as an internal control to ensure that the resistant cells still maintained the same high level of maspin expression and could not be further induced by DOC. Routine staining of the entire gel with Brilliant blue indicated that all lanes received the same amount of protein.

Note: *Reduction in maspin protein levels after incubation with the specific siRNA maspin probe was statistically significant compared with untreated control cells $(P=0.0078)$.

Abbreviations: siRNA, small interfering RNA; SEM, standard error of the mean; DOC, deoxycholate.

\section{Colon resections from patients with colonic tumors} and evaluation of "field defects"

Tissue samples $(n=106)$ from non-neoplastic colonic mucosa, adenomas, and adenocarcinomas present in the resected colon segments obtained at surgery were immunostained for maspin, and a relative score of $0,0.5$ (minimal staining), 1, 2, 3, or 4 was assigned to each of these tissues (Table 2). Non-neoplastic tissues in resected colon segments that harbored a tumor (in ten patients) were scored to identify possible "field defects" associated with maspin expression. Samples of the non-neoplastic mucosa were taken adjacent to the tumor on the proximal and distal sides (P0, D0), $2 \mathrm{~cm}$ away on the proximal and distal side (P2, D2) and near the surgical margins (PMAX, DMAX). The adenomas/adenocarcinomas displayed a maspin score that was $\sim 3$ times $(2.17 / 0.66)$ greater than the maspin score in tissue samples taken from non-neoplastic colonic mucosa present in the same colon resection (Figure 5). The overall mean maspin expression in the adenomas/adenocarcinomas was significantly increased compared with the mean maspin expression in the non-neoplastic colonic mucosa in the same resected tissues $(P=0.00002)$ (Table 3$)$, and significantly increased over that of control colonic mucosa from patients with no colonic neoplasia $(P=0.00004)$ (Table 3$)$. There was no significant difference between the non-neoplastic colonic mucosa of patients with a colonic neoplasia (Table 2) and the colonic mucosa of patients with no colonic neoplasia (Table 1).

It is interesting that the non-neoplastic mucosa of the UC patient, shown in Figure 3, exhibited a high expression of maspin (2.92 \pm 0.28$)$, which was significantly greater $\left(P=7.52 \times 10^{-16}\right)$ than the mean $(0.66 \pm 0.20)$ of the nonneoplastic mucosa of patients with sporadic adenomas/ adenocarcinomas (Table 2). This comparison of images of non-neoplastic mucosa from inflammatory bowel disease (Figure 3) and sporadic colon cancer (Figure 4) underscores the different etiologies of these two diseases. This will be briefly discussed in the discussion section.

\section{High expression of maspin begins at the polyp/} adenoma stage of sporadic colon carcinogenesis Since high maspin expression was not observed as "field defects" in the 61 samples of non-neoplastic colonic mucosa obtained from colon resections of patients with large sporadic adenomas or adenocarcinomas, maspin expression was evaluated in a number of early colonic growths, which included hyperplastic and adenomatous polyps, to determine if high maspin expression was characteristic of the polyp stage of colon cancer progression (Table 4). Statistically increased maspin expression occurred at the polyp stage (Table 4) compared with the non-neoplastic mucosa of control patients (Table 1) $\left(P=9.10 \times 10^{-13}\right)$ and the non-neoplastic mucosa adjacent to hyperplastic polyps and adenomatous polyps $\left(P=8.37 \times 10^{-7}\right)$ (Table 4). There was no statistical difference in maspin expression of polyps compared with that of adenocarcinomas $(P=0.43)$ (Table 3$)$. Images of maspin expression in non-neoplastic mucosa from control subjects and from patients with colonic tumors are shown in Figure 4. The non-neoplastic colonic mucosa immediately adjacent to polyps was also evaluated for maspin expression (Table 4) and it was determined that there was no significant difference in maspin expression compared with the non-neoplastic colonic mucosa of control subjects (Table 1) $(P=0.18)$ and that of the non-neoplastic colonic mucosa at some distance from colonic tumors (Table 2$)(P=0.44)$. Images of polyps and adjacent non-neoplastic mucosa are shown in Figure 6. Therefore, it appears that increased expression of maspin is associated with the formation of a tumor at the earliest macroscopic stage of tumor growth visible on routine colonoscopy.

\section{Discussion}

Previous work from the authors' laboratory indicated that persistent exposure of apoptosis-sensitive colon epithelial 

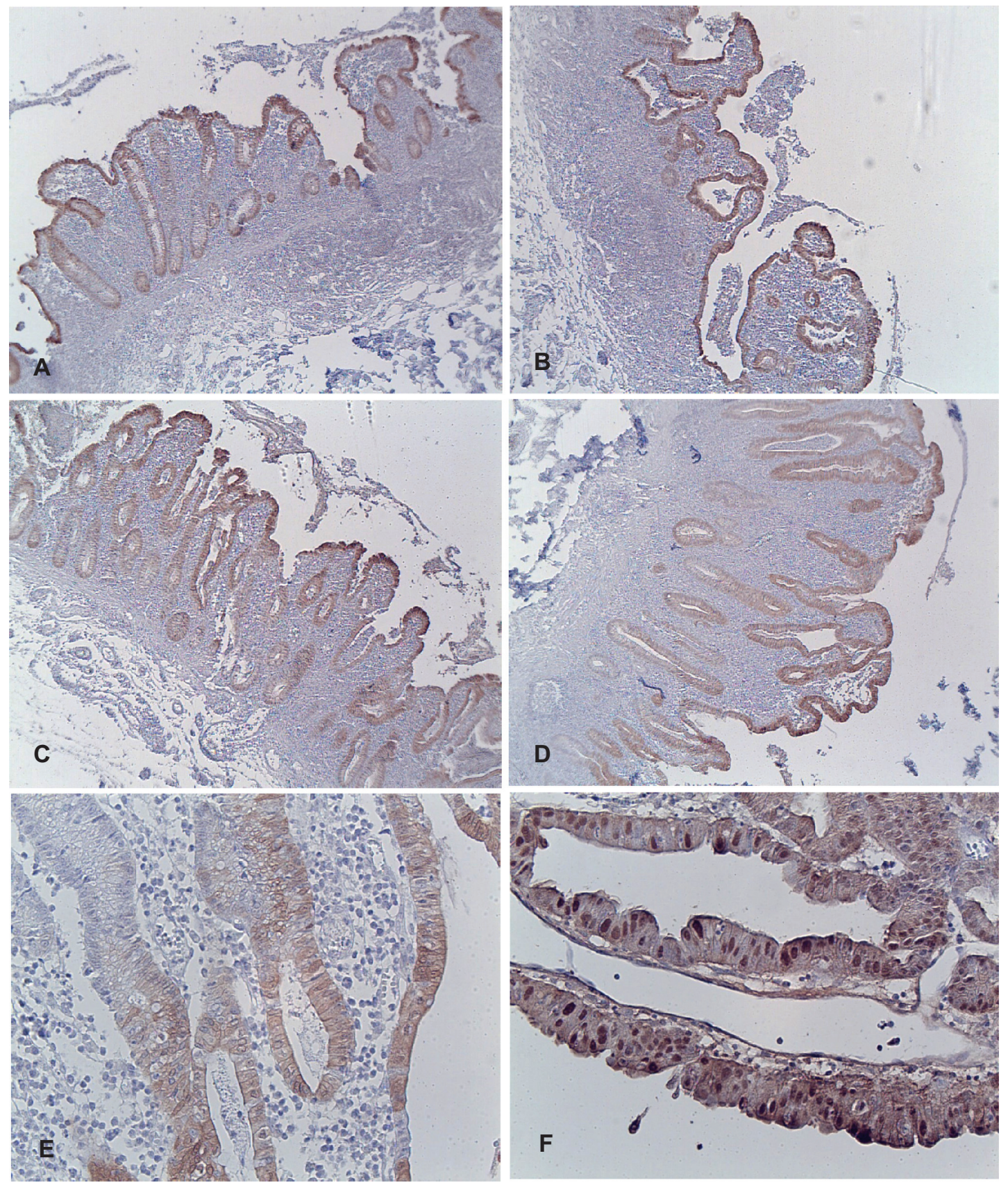

Figure 3 Composite of images of colonic tissue from a patient with ulcerative colitis and adenocarcinoma stained for maspin expression. (A) Non-neoplastic mucosa taken adjacent to the cancer on the proximal side. (B) Non-neoplastic mucosa taken adjacent to the cancer on the distal side. (C) Non-neoplastic mucosa taken $3 \mathrm{~cm}$ away from the cancer on the proximal side. (D) Non-neoplastic mucosa taken $9 \mathrm{~cm}$ away from the cancer on the distal side. (E) Higher magnification of representative non-neoplastic mucosa taken $3 \mathrm{~cm}$ away from the cancer on the distal side; note the predominately cytoplasmic staining of maspin. (F) Note the increased overall expression of maspin in the adenocarcinoma; prominent nuclear staining of maspin is evident.

Notes: Images A-D were taken with a $4 \times$ objective lens; images $\mathbf{E}$ and $\mathbf{F}$ were taken with a $20 \times$ objective lens; all images counterstained with hematoxylin.

cells to DOC, a hydrophobic bile acid, for $\sim 40$ weeks led to the selection of cells that were stably resistant to DOC. ${ }^{5}$ These resistant cells were characterized at the molecular and cellular levels to understand some of the pathways and key proteins that may have been modulated to account for their resistance to apoptosis. ${ }^{533,34,44}{ }^{46}$ In one study, two-dimensional gel electrophoresis and mass spectroscopy of the HCT-116RC cell line, revealed a dramatic increase in maspin protein expression. ${ }^{5}$ The DOC-induced maspin expression may have been the result of DOC-induced DNA damage and/or oxidative stress, since the maspin promoter contains binding sites for major transcription factors that respond to DNA damage and/or oxidative stress, such as NF-kappaB, ${ }^{47,48} \mathrm{SP} 1,{ }^{49,50}$ p53, ${ }^{51-53}$ ATF-2, ${ }^{54}$ and NKX3-1 ${ }^{55}$ (Figure 7). 
Table I Maspin expression in the colonic mucosa of patients with no colonic polyps, cancer or inflammatory bowel disease

\begin{tabular}{|c|c|c|c|c|c|c|c|c|c|c|c|}
\hline Patients & $I^{\mathbf{a}}$ & 2 & 3 & 4 & 5 & 6 & 7 & 8 & 9 & 10 & $\begin{array}{l}\text { Mean maspin } \\
\text { expression }\end{array}$ \\
\hline $\begin{array}{l}\text { Normal colon resection I } \\
\text { (sarcoma patient) }\end{array}$ & 0.5 & 0.5 & 0.5 & 0.5 & 0.5 & 0.5 & 0.5 & $-{ }^{\mathrm{b}}$ & - & - & $0.50 \pm 0$ \\
\hline $\begin{array}{l}\text { Normal colon resection } 2 \\
\text { (sarcoma patient) }\end{array}$ & 0.5 & 0.5 & I & 1 & 0.5 & - & - & - & - & - & $0.70 \pm 0.27$ \\
\hline Diverticulitis patient I & 0.5 & I & 1 & 1 & 1 & I & - & - & - & - & $0.92 \pm 0.20$ \\
\hline Diverticulitis patient 2 & 0.5 & 0.5 & 0.5 & 0.5 & 0.5 & 0.5 & 0.5 & - & - & - & $0.50 \pm 0$ \\
\hline Colonoscopy biopsies & 0.5 & 0.5 & 0.5 & 0.5 & 0.5 & 0.5 & I & 0.5 & I & I & $0.65 \pm 0.24$ \\
\hline
\end{tabular}

Notes: Mean overall maspin expression of control tissues $=0.64 \pm 0.23$; ${ }^{a}$ tissue sample; ${ }^{b}$ no tissue available.

Maspin is a multifunctional protein whose expression in different anatomic locations may affect different aspects of carcinogenesis. ${ }^{56}$ Although maspin acts as a tumor suppressor in the breast and has a pro-apoptotic role in that tissue, the authors have shown for the first time that maspin acts as an anti-apoptotic protein in colon epithelial cells. This may explain its role as a stress-response protein in the colon (Figure 7), since cells need to evade cell death so that oxidative DNA damages can be adequately repaired. ${ }^{10}$ In fact, knockout of both maspin genes is embryonically lethal, ${ }^{57}$ indicating its importance to cell survival or function. However, extended upregulation of anti-apoptotic proteins can have deleterious consequences. Apoptosis-resistant cells that harbor unrepaired DNA damages and enter the pool of proliferating cells may propagate mutations, some of which may lead to cancer ${ }^{58,59}$ (Figure 7).

The mechanisms by which maspin inhibits apoptosis in the colon are not known.

The maspin protein has 8 cysteines ${ }^{60}$ and exists in several molecular configurations that are dependent upon degree of oxidative stress and the extent of intramolecular disulfide bridge formation. ${ }^{61}$ In addition to the generation of oxidative stress, reactive oxygen species can have physiological effects on cells because of their ability to positively or negatively affect protein function, ${ }^{62}$ thereby affecting different signaling pathways $^{63,64}$ (Figure 7). Since maspin can interact with at least 20 different molecules, ${ }^{56}$ the effect of oxidative stress on maspin and the downstream maspin-protein interactions can ultimately affect cell survival and carcinogenesis. Since caspases have cysteines as a critical amino acid affecting their pro-apoptotic function, ${ }^{65}$ it is possible that maspin may physically interact with and inhibit caspases through disulfide bridge formation (Figure 7). Studies in different cell types indicate that maspin can interact with specific proteins that may reduce cellular stresses and cell death, such as glutathione S-transferase (GST) ${ }^{66}$ and heat shock protein 70 (HSP70) (Figure 7). ${ }^{66} \mathrm{GST}$ is a major antioxidant defense protein that protects epithelial cells in aberrant crypt foci from DOCinduced apoptosis, ${ }^{67}$ and the activity of GST is increased by its interaction with maspin. ${ }^{66}$ HSP70 serves to protect against cell death since it sequesters apoptosis-inducing factor (AIF) in the cytoplasm, ${ }^{68-73}$ thereby preventing the translocation of AIF to the nucleus and binding to DNA.74,75 When translocation of AIF to the nucleus occurs, it induces DNA condensation and the recruitment of endogenous endoand exonucleases, resulting in DNA fragmentation. ${ }^{76,77}$ The signaling pathways that lead to apoptosis are most complex, and maspin may interfere, through physical interactions, with the action or activity of apoptosis regulatory proteins (Figure 7). The survival of cells depends not only on inhibiting pro-cell death pathways, but the activation of prosurvival pathways. Since the authors previously reported that the $\mathrm{NF}-\mathrm{KB}$ and autophagy pathways are constitutively activated and contributed to the survival of the resistant HCT-116RC cells, ${ }^{5,33}$ maspin may also interact with key proteins in these prosurvival pathways (Figure 7). A full understanding of maspin's role as an anti-apoptotic protein will benefit from technologies such as yeast 2-hybrid analyses, co-immunoprecipitations, cDNA microarrays, proteomic analyses and transmission electron microscopy after siRNA knockdown, and confocal microscopy for organelle localizations under different experimental conditions.

To understand maspin's role in colon carcinogenesis, an immunohistochemical analysis of maspin expression was performed in the epithelial cells of macroscopically normal colonic mucosa, polyps, adenomas and adenocarcinomas. It was found that maspin is highly expressed at the polyp and adenocarcinoma stages of colon carcinogenesis, which is consistent with others' results. ${ }^{29}$ High maspin expression, however, was not observed as "field defects" in the non-neoplastic colonic mucosa, ${ }^{78}$ either directly adjacent to a tumor or at different distances proximal or distal to the tumor. In contrast, "field defects" were observed in the decreased expression of the DNA repair proteins Pms2, 


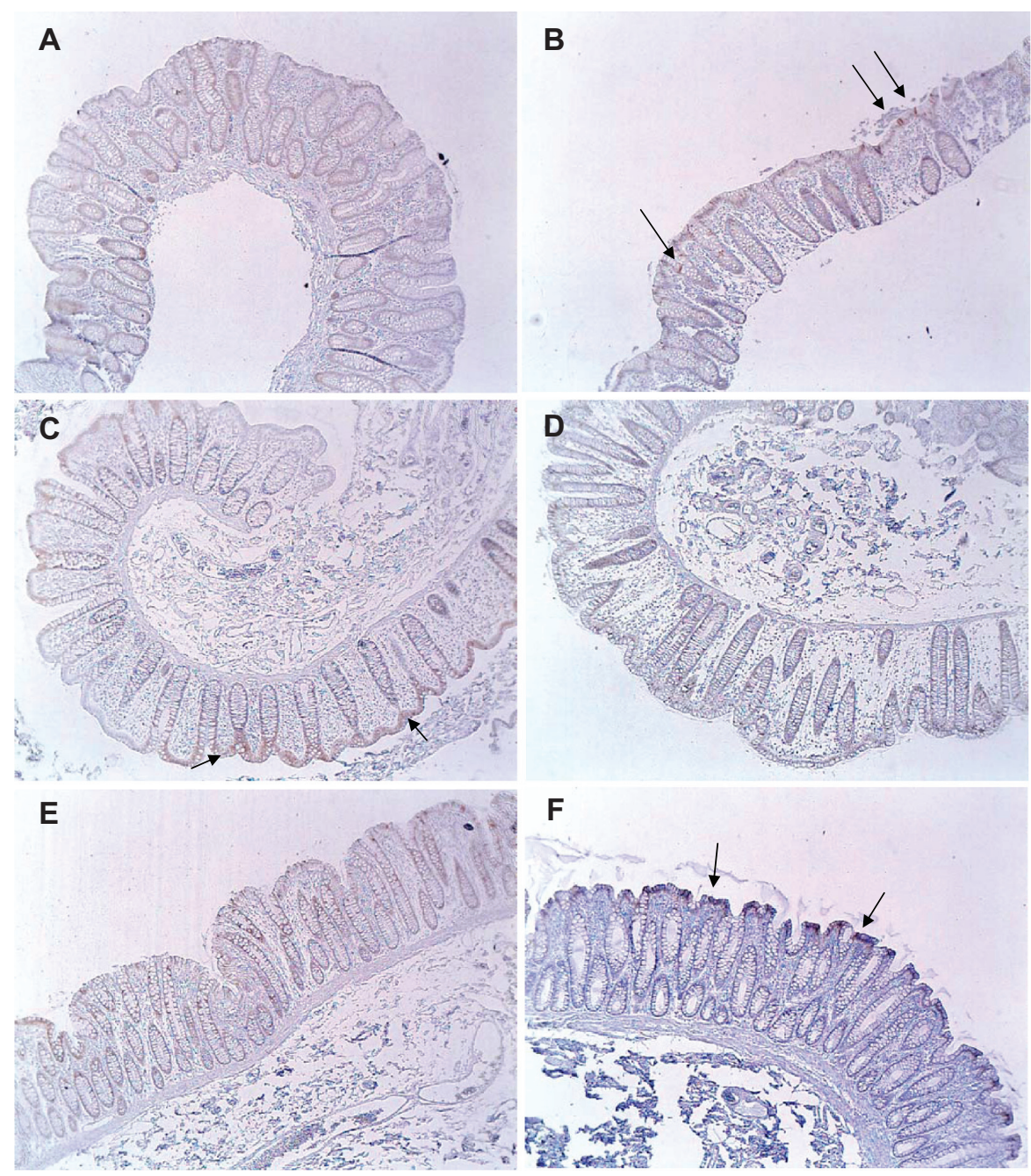

Figure 4 Variability in maspin expression in non-neoplastic colonic mucosa obtained from normal subjects and patients with colonic tumors (4× objective). (A) Normal mucosa obtained from a healthy patient during routine colonoscopy. This image shows a low overall expression of maspin; (B) normal mucosa obtained from a healthy patient during routine colonoscopy. This image shows focal staining in individual cells (arrows); (C) normal mucosa obtained from a colon resection from a patient who had a sarcoma surgically removed. The sarcoma was external to the body wall and the patient had received no prior radiation or chemotherapy. This image shows low overall staining predominantly at the top of the crypts (arrows); (D) region of colon $2 \mathrm{~cm}$ proximal to a large tubulovillous adenoma. This image shows a low overall expression of maspin; (E) region of colon $2 \mathrm{~cm}$ proximal to a large tubulovillous adenoma. This image shows a low overall expression of maspin; (F) region of colon near the distal margin of a colon resection from a patient with a colon cancer. This image shows low overall staining predominantly at the top of the crypts (arrows).

Table 2 Maspin expression in non-neoplastic colonic mucosa and tumors in colonic resections of patients with sporadic adenomas and adenocarcinomas

\begin{tabular}{llllllll}
\hline Patient category & PMAX & P2 & P0 & Adenoma/Cancer & D0 & D2 & DMAX \\
\hline TVA & 0.5 & $\mathrm{I}$ & - & 3 & 0.5 & $\mathrm{I}$ & 0.5 \\
TVA & 0.5 & 0.5 & 0.5 & $\mathrm{I}$ & 0.5 & 0.5 & 0.5 \\
TVA & $\mathrm{I}$ & 0.5 & 0.5 & 3 & 0.5 & 0.5 & $\mathrm{I}$ \\
Adenoma/CA & 0.5 & 0.5 & $\mathrm{I}$ & $3 / 2$ & 0.5 & 2 & - \\
Adenoma/CA & 0.5 & 0.5 & 0.5 & $2 / 2$ & 0.5 & 0.5 & 0.5 \\
Adenocarcinoma & 0.5 & 0.5 & 0.5 & 3 & 0.5 & 0.5 & 0.5 \\
Adenocarcinoma & - & $\mathrm{I}$ & 0.5 & 2 & $\mathrm{I}$ & 0.5 & 0.5 \\
Adenocarcinoma & $\mathrm{I}$ & $\mathrm{I}$ & 2 & 3 & $\mathrm{I}$ & 0.5 & $\mathrm{I}$ \\
Adenocarcinoma & $\mathrm{I}$ & $\mathrm{I}$ & 0.5 & $\mathrm{I}$ & 0.5 & 0.5 & $\mathrm{I}$ \\
Adenocarcinoma & - & 0.5 & 0.5 & $\mathrm{I}$ & 0.5 & - & 0.5 \\
Mean score \pm SD & $0.69 \pm 0.26$ & $0.70 \pm 0.26$ & $0.72 \pm 0.5 \mathrm{I}$ & $2.17 \pm 0.83$ & $0.6 \pm 0.21$ & $0.72 \pm 0.5 \mathrm{I}$ & $0.67 \pm 0.25$ \\
\hline
\end{tabular}

Notes: Samples of the non-neoplastic mucosa were taken adjacent to the tumor on the proximal and distal sides (P0, D0), $2 \mathrm{~cm}$ away on the proximal and distal side (P2, D2) and near the surgical margins (PMAX, DMAX).

Abbreviations: $C A$, carcinoma; DMAX, maximum distance from the tumor at the distal margin of the resection; PMAX, maximum distance from the tumor at the proximal margin of the resection; SD, standard deviation; TVA, tubulovillous adenoma. 


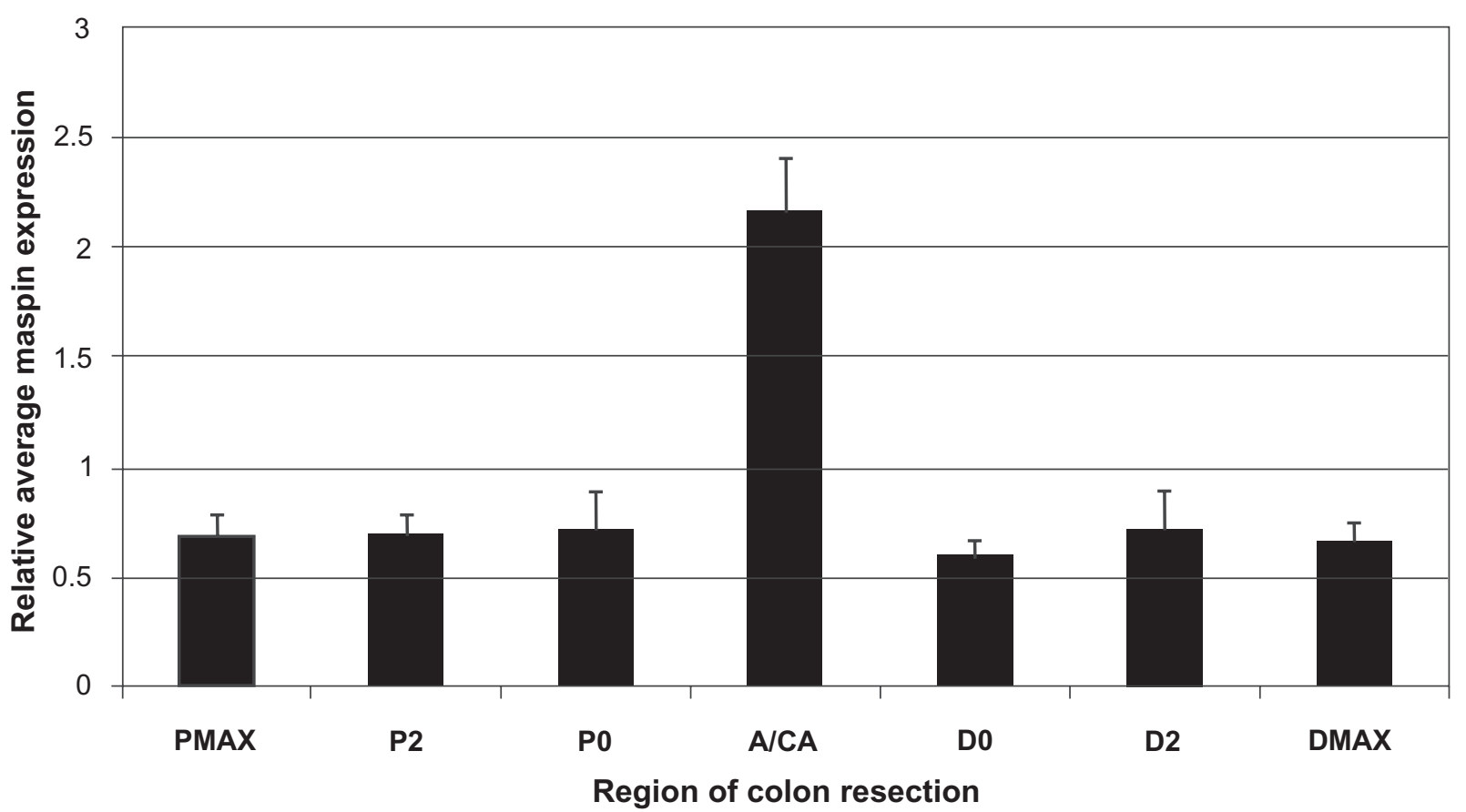

Figure 5 Histogram displaying the average maspin score \pm SEM in the non-neoplastic mucosa at different distances from the colonic neoplasms of 10 patients with a large adenoma (A) or cancer (CA). Samples of the non-neoplastic mucosa were taken adjacent to the tumor on the proximal and distal sides (P0, D0), $2 \mathrm{~cm}$ away on the proximal and distal side (P2, D2) and near the surgical margins (PMAX, DMAX).

Abbreviation: SEM, standard error of the mean.

ERCC1, Xpf, and Ku86, ${ }^{41,79}$ and in an apoptosis-related mitochondrial protein, cytochrome c oxidase. ${ }^{40,42}$ It is possible that a dramatic and sustained increase in maspin expression at the polyp stage may drive sporadic colon tumorigenesis through its anti-apoptotic function and interaction with other survival signaling pathways in the colon. The anti-apoptotic function of maspin might also allow cells in a field of genomic instability within polyps and adenocarcinomas to proliferate and undergo further clonal expansion (Figure 7).

Although DOC was previously thought to be a promoter of colon cancer, the authors have previously documented that DOC is a true carcinogen. ${ }^{80}$ The authors found that prolonged dietary feeding of DOC to mice (to produce the colonic level of DOC found in the colons of humans on a high-fat diet) was responsible for the formation of both adenomas ${ }^{81}$ and adenocarcinomas ${ }^{80}$ in the mouse proximal colon. The
DOC-induced increase in maspin expression previously documented ${ }^{5}$ may explain the increase in maspin expression in ampullary adenocarcinomas that occur near the ampulla of Vater, ${ }^{82}$ through which copious amounts of bile are released into the small intestine (see endoscopy image in Rana et a ${ }^{83}$ ). DOC contained in the secreted bile may be responsible for the formation of these rare adenocarcinomas that occur in the small intestine.

An interesting question has emerged from the authors' studies concerning the role of maspin expression during colon carcinogenesis. Since maspin expression first appears significantly increased at the polyp stage of sporadic colon carcinogenesis, but is significantly increased in the non-neoplastic mucosa of patients with inflammatory bowel disease, what is the role of inflammation in sporadic colon cancer? An increase in maspin expression as a "field defect" was not observed in the colon of patients with

Table 3 Mean maspin expression in non-neoplastic colonic mucosa of colon resections from patients with and without colonic neoplasia: comparison to mean maspin expression of adenomas and adenocarcinomas

\begin{tabular}{|c|c|c|}
\hline $\begin{array}{l}\text { Control colonic mucosa from patients } \\
\text { without colonic neoplasia }(n=9)\end{array}$ & $\begin{array}{l}\text { Non-neoplastic colonic mucosa from patients } \\
\text { with colonic neoplasia }(n=10)\end{array}$ & $\begin{array}{l}\text { Adenomas/Adenocarcinomas } \\
(n=12)\end{array}$ \\
\hline $0.65 \pm 0.20$ & $0.66 \pm 0.20$ & $2.17 \pm 0.83$ \\
\hline \multirow[t]{2}{*}{ Student's $t$-test } & $P=0.93^{\prime}$ & $P=0.00002^{2}$ \\
\hline & & $P=0.00004^{3}$ \\
\hline
\end{tabular}

Notes: 'Non-significant difference in mean maspin expression compared with control colonic mucosa; ${ }^{2}$ significant difference in maspin expression compared with nonneoplastic colonic mucosa from patients with colonic neoplasia; ${ }^{3}$ significant difference in maspin expression compared with control colonic mucosa. 
Table 4 Comparison of maspin expression in hyperplastic polyps, adenomatous polyps, adenocarcinomas and non-neoplastic mucosa

\begin{tabular}{lll}
\hline Polyps & Adenocarcinomas & $\begin{array}{l}\text { Non-neoplastic mucosa } \\
\text { adjacent to polyps }\end{array}$ \\
\hline $3^{*}$ & 3 & 3 \\
$I^{*}$ & 2 & 0.5 \\
$3^{*}$ & 2 & 1 \\
$2^{*}$ & 3 & 0.5 \\
3 & 1 & 0.5 \\
3 & 2 & 0.5 \\
3 & 1 & 0.5 \\
3 & 1 & 0.5 \\
2 & 3 & 0.5 \\
3 & 3 & 0.5 \\
2 & 2 & 0.5 \\
2 & 4 & 0.5 \\
I & 2 & 0.5 \\
& 0.5 & 1 \\
& & 0.5 \\
Mean \pm SD $=$ & Mean \pm SD $=$ & 3 \\
$2.38 \pm 0.77$ & $2.11 \pm 1.00$ & Mean \pm SD $=$ \\
\hline
\end{tabular}

Note: *Large adenomas from colon resections. Abbreviation: SD, standard deviation.

sporadic colon cancer, and distinct areas of inflammatory infiltrates, as observed in UC, were absent in the tissues examined in the present study. There appear to be multiple pathways to colon cancer, including inherited genetic mutations, inflammatory conditions of the colon (eg, UC, Crohn's disease), and a high-fat/low-vegetable diet. The development of sporadic colon cancer appears to result, in large part, from dietary factors. Since increased hydrophobic bile acids are associated with a high fat diet, persistent exposure to these bile acids over decades can induce multiple stresses on colon cells, causing DNA damage, oxidative/ nitrosative stress, and mitotic perturbations, ${ }^{34,46,84-90}$ resulting in the gradual selection of clones with a growth advantage (Figure 7). The increase in maspin at the polyp stage in sporadic colon cancer may then reflect the proliferation of persistently stressed clones of cells. Since maspin is clearly a stress-response protein, it is possible that it responds to specific stresses associated with the polyp stage of colon carcinogenesis, which may be accentuated by a decrease in key DNA repair proteins, for example. Since the tissues of the polyps/cancers with high maspin expression also do not show an apparent inflammatory infiltrate, the association between maspin and inflammation in sporadic colon cancer cannot be made in the present study. In inflammatory bowel disease, large areas of the colon may be in a "highly stressed state," as a result of multiple deleterious factors secreted from inflammatory cells, resulting in persistently increased maspin expression (and increased apoptosis resistance) in the non-neoplastic mucosa. The normal mucosa of patients with UC can harbor significant DNA damage, oxidative
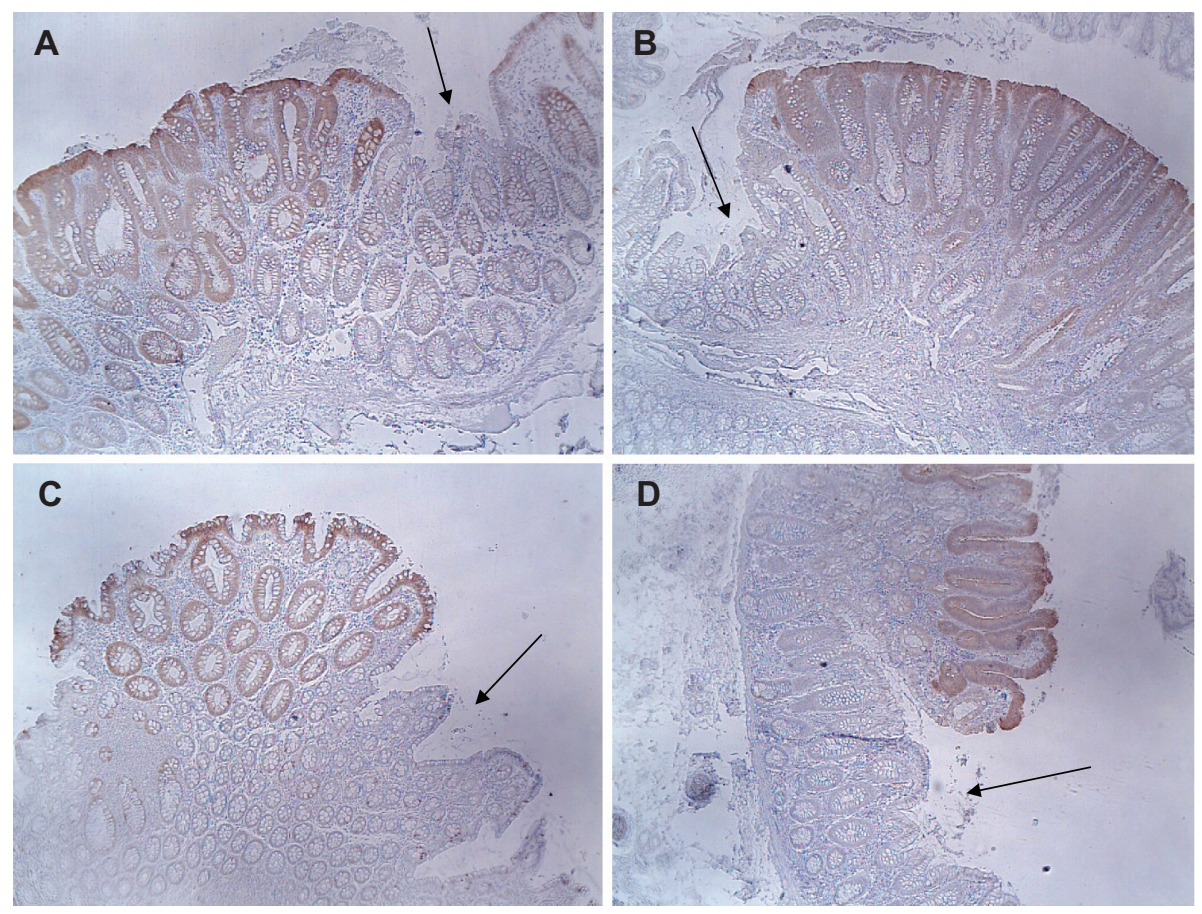

Figure 6 Increased maspin expression in polyps (brown color) compared with minimal expression in adjacent non-neoplastic colonic mucosa (see arrows). (A) Adenomatous polyp; (B) adenomatous polyp; (C) hyperplastic polyp; (D) adenomatous polyp ( $4 \times$ objective). 


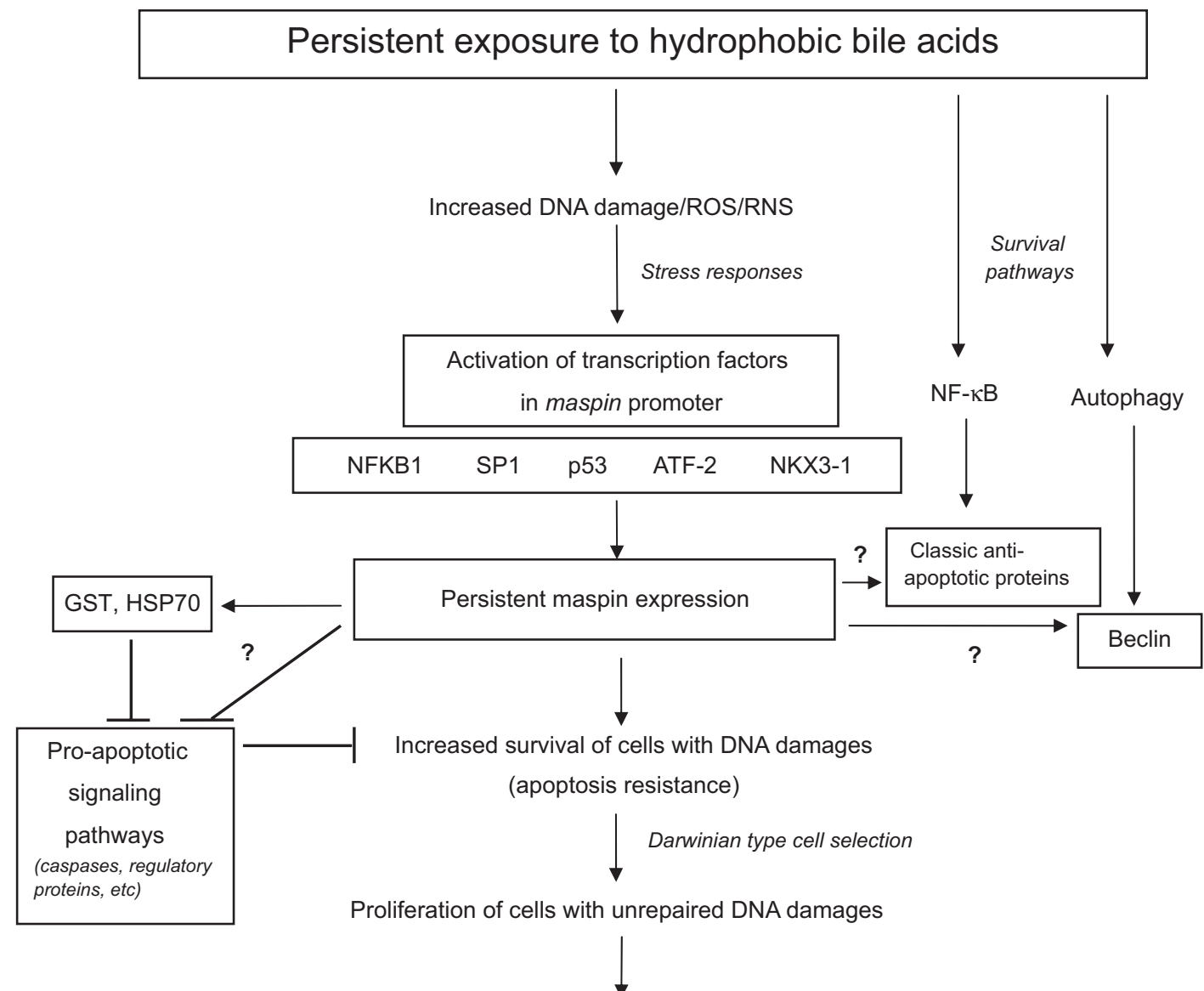

Increased number of cells with mutations

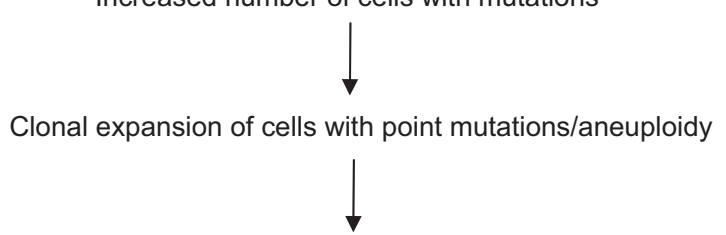

Adenomatous polyps

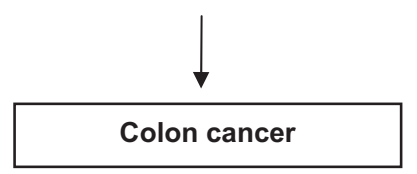

Figure 7 Molecular signaling pathways that may be activated after persistent exposure of cells to hydrophobic bile acids. Since hydrophobic bile acids can perturb cellular membranes, surface molecules can be activated that generate reactive oxygen and nitrogen species. This can cause oxidative DNA damage and the activation of genes associated with the stress response and the activation of transcription factors that turn on genes associated with cell survival. These survival genes include maspin, classic anti-apoptotic genes that are NF-אB-activated, and autophagy-related genes, such as beclin. In order for cells with DNA damages to proliferate, they must evade cell death pathways. Maspin may inhibit these pro-apoptotic pathways through interaction with proteins (eg, GST, HSP70) known to interact with maspin and to inhibit apoptosis. Future studies, designated by question marks, indicate possible interactions with apoptosis regulatory proteins, caspases (executioners of apoptosis) and proteins associated with the pro-survival NF- $\kappa B$ and autophagic pathways. Some of these potential maspin-target protein interactions may result in activation or inhibition of the target proteins. Abbreviations: ATF-2, activating transcription factor 2; GST, glutathione S-transferase; HSP70, heat shock protein 70; NF- $\mathrm{KB}$, redox-sensitive transcription factor; NFKBI, nuclear factor NF-KB pl05 subunit; NKX3-I, product of the homeobox gene that functions as a transcription factor; p53, tumor protein 53; RNS, reactive nitrogen species; ROS, reactive oxygen species; SPI, transcription factor that responds to physiological and pathological stimuli.

damage, and even mutations in cancer-related oncogenes, ${ }^{91,92}$ a situation that may increase the probability of development of neoplasia under these severe inflammatory conditions.

In future studies, it will be important to understand the mechanisms by which maspin functions as an anti-apoptotic protein, and to determine its role in early preneoplastic lesions. It may also serve as a biomarker to evaluate colon cancer risk and tumor progression, perhaps in conjunction with other biomarkers, such as increased 8-oxoguanine and loss of DNA repair proteins. 


\section{Acknowledgments}

Supported by NIH grant \#R01CA119087 and Biomedical Diagnostics \& Research Inc, Tucson, AZ.

\section{Disclosure}

The authors report no conflicts of interest in this work.

\section{References}

1. Bernstein H, Bernstein C, Payne CM, Garewal H. Recent molecular evidence illuminates the decades-long debate on the role of dietary fat in colon carcinogenesis. $J$ Cancer Integr Med. 2004;2: 107-109.

2. Bernstein H, Bernstein C, Payne CM, Dvorakova K, Garewal H. Bile acids as carcinogens in human gastrointestinal cancers. Mutat Res. 2005;589(1):47-65.

3. Bernstein C, Payne CM, Dvorak, K, Bernstein H. Role of bile acids in gastrointestinal carcinogenesis. US Gastroenterol Hepatol Rev. 2008; 4:68-72.

4. Bernstein H, Bernstein C, Payne CM, Dvorak K. Bile acids as endogenous etiologic agents in gastrointestinal cancer. World J Gastroenterol. 2009;15(27):3329-3340.

5. Crowley-Weber CL, Payne CM, Gleason-Guzman M, et al. Development and molecular characterization of colon cell lines resistant to the tumor promoter and multiple stress-inducer, deoxycholate. Carcinogenesis. 2002;23(12):2063-2080

6. McCormick F. Cancer: survival pathways meet their end. Nature. 2004;428(6980):267-269.

7. Wendel HG, De Stanchina E, Fridman JS, et al. Survival signalling by Akt and eIF4E in oncogenesis and cancer therapy. Nature. 2004;428(6980):332-337.

8. Payne CM, Bernstein H, Bernstein C, Garewal H. The role of apoptosis in biology and pathology: Resistance to apoptosis in colon carcinogenesis. Ultrastruct Pathol. 1995;19(4):221-248.

9. Bernstein C, Bernstein H, Garewal H, et al. A bile acid-induced apoptosis assay for colon cancer risk, and associated quality control studies Cancer Res. 1999;59(10):2353-2357.

10. Payne CM, Bernstein C, Dvorak K, Bernstein H. Hydrophobic bile acids, genomic instability, Darwinian selection and colon carcinogenesis. Clin Exp Gastroenterol. 2008;1:19-47.

11. Payne CM, Crowley-Skillicorn C, Bernstein C, Holubec H, Bernstein H Molecular and cellular pathways associated with chromosome $1 \mathrm{p}$ deletion during colon carcinogenesis. Clin Exp Gastroenterol. 2011; 4:75-119.

12. Sheng S, Pemberton PA, Sager R. Production, purification, and characterization of recombinant maspin proteins. J Biol Chem. 1994;269(49) 30988-30993.

13. Schneider SS, Schick C, Fish KE, et al. A serine proteinase inhibitor locus at $18 \mathrm{q} 21.3$ contains a tandem duplication of the human squamous cell carcinoma antigen gene. Proc Natl Acad Sci U SA. 1995; 92(8):3147-3151.

14. Zou Z, Anisowicz A, Hendrix MJ, et al. Maspin, a serpin with tumorsuppressing activity in human mammary epithelial cells. Science. 1994; 263(5146):526-529.

15. Seftor R, Seftor EA, Sheng S, Pemberton PA, Sager R, Hendrix MJC. Maspin suppresses the invasive phenotype of human breast carcinoma. Cancer Res. 1998;58(24):5681-5685.

16. Pemberton PA, Wong DT, Gibson HL, et al. The tumor suppressor maspin does not undergo the stressed to relaxed transition or inhibit trypsin-like serine proteases. Evidence that maspin is not a protease inhibitory serpin. J Biol Chem. 1995;270(26):15832-15837.

17. Narayan M, Twining S. Focus on molecules: maspin. Exp Eye Res. 2010;90(1):2-3.

18. Liu J, Yin S, Reddy N, Spencer C, Sheng S. Bax mediates the apoptosissensitizing effect of maspin. Cancer Res. 2004;64(5):1703-1711.
19. Li Z, Shi HY, Zhang M. Targeted expression of maspin in tumor vasculatures induces endothelial cell apoptosis. Oncogene. 2005;24(12): 2008-2019.

20. Latha K, Zhang W, Cella N, Shi HY, Zhang M. Maspin mediates increased tumor cell apoptosis upon induction of the mitochondrial permeability transition. Mol Cell Biol. 2005;25(5):1737-1748.

21. Zhang W, Shi HY, Zhang M. Maspin overexpression modulates tumor cell apoptosis through the regulation of Bcl-2 family proteins. $B M C$ Cancer. 2005;5:50.

22. Schaefer JS, Zhang M. Targeting maspin in endothelial cells to induce cell apoptosis. Expert Opin Ther Targets. 2006;10(3):401-408.

23. Li X, Chen D, Yin S, et al. Maspin augments proteasome inhibitorinduced apoptosis in prostate cancer cells. J Cell Physiol. 2007;212(2): 298-306.

24. Toillon RA, Lagadec C, Page A, et al. Proteomics demonstration that normal breast epithelial cells can induce apoptosis of breast cancer cells through insulin-like growth factor-binding protein-3 and maspin. Mol Cell Proteomics. 2007;6(7):1239-1247.

25. McKenzie S, Sakamoto S, Kyprianou N. Maspin modulates prostate cancer cell apoptotic and angiogenic response to hypoxia via targeting AKT. Oncogene. 2008;27(57):7171-7179.

26. Bettstetter M, Woenckhaus M, Wild PJ, et al. Elevated nuclear maspin expression is associated with microsatellite instability and high tumour grade in colorectal cancer. J Pathol. 2005;205(5):606-614.

27. Boltze C. Loss of maspin is a helpful prognosticator in colorectal cancer: a tissue microarray analysis. Pathol Res Pract. 2005;200(11-12): 783-790.

28. Cao D, Wilentz RE, Abbruzzese JL, Ho L, Maitra A. Aberrant expression of maspin in idiopathic inflammatory bowel disease is associated with disease activity and neoplastic transformation. Int $J$ Gastrointest Cancer. 2005;36(1):39-46.

29. Zheng $\mathrm{H}$, Tsuneyama $\mathrm{K}$, Cheng $\mathrm{C}$, et al. Maspin expression was involved in colorectal adenoma-adenocarcinoma sequence and liver metastasis of tumors. Anticancer Res. 2007;27(1A):259-265.

30. Markl B, Arnholdt HM, Jahnig H, et al. Shift from cytoplasmic to nuclear maspin expression correlates with shorter overall survival in nodenegative colorectal cancer. Hum Pathol. 2010;41(7):1024-1033.

31. Pasz-Walczak G, Salagacka A, Potemski P, Balcerczak E, Korder R, Mirowski M. Maspin and Nm23-H1 expression in colorectal cancer Neoplasma. 2010;57(2):95-101.

32. Payne CM, Crowley-Weber CL, Dvorak K, et al. Mitochondrial perturbation attenuates bile acid-induced cytotoxicity. Cell Biol Toxicol. 2005;21(5-6):215-231.

33. Payne CM, Crowley-Skillicorn C, Holubec H, et al. Deoxycholate, an endogenous cytotoxin/genotoxin, induces the autophagic stress-survival pathway: Implications for colon carcinogenesis. J Toxicol. 2009:1-14; article ID 785907; doi:10.1155/2009/785907.

34. Payne CM, Crowley-Skillicorn C, Bernstein C, Holubec H, Moyer MP, Bernstein H. Hydrophobic bile acid-induced micronuclei formation, mitotic perturbations and decreases in spindle checkpoint proteins: Relevance to genomic instability in colon carcinogenesis. Nutr Cancer 2010;62(6):825-840.

35. Yan Q, Briehl M, Crowley CL, Payne CM, Bernstein H, Bernstein C. The NAD+ precursors, nicotinic acid and nicotinamide upregulate glyceraldehyde-3-phosphate dehydrogenase and glucose-6-phosphate dehydrogenase mRNA in Jurkat cells. Biochem Biophys Res Commun. 1999;255(1):133-136.

36. Qi L, Sit KH. Housekeeping genes commanded to commit suicide in CpG-cleavage commitment upstream of Bcl-2 inhibition in caspasedependent and independent pathways. Mol Cell Biol Res Comm. 2000; 3(5):319-327.

37. Dittmer A, Dittmer J. Beta-actin is not a reliable loading control in Western blot analysis. Electrophoresis. 2006;27(14):2844-2845.

38. Kuzelova K, Pluskalova M, Grebenova D, Pavlaskova K, Halada P, Hrkal Z. Changes in cell adhesivity and cytoskeleton-related proteins during imatinib-induced apoptosis of leukemic JURL-MK1 cells. J Cell Biochem. 2010;111(6):1413-1425. 
39. Bernstein H, Holubec H, Warneke JA, et al. Patchy field defects of apoptosis resistance and dedifferentiation in flat mucosa of colon resections from colon cancer patients. Ann Surg Oncol. 2002;9(5):505-517.

40. Payne CM, Holubec H, Bernstein C, et al. Crypt-restricted loss and decreased protein expression of cytochrome c oxidase subunit I as potential hypothesis-driven biomarkers of colon cancer risk. Cancer Epidemiol Biomarkers Prevent. 2005;14(9):2066-2075.

41. Bernstein H, Prasad A, Holubec H, et al. Reduced Pms2 in nonneoplastic flat mucosa from patients with colon cancer correlates with reduced apoptosis competence. Appl Immunohistochem Mol Morphol. 2006;14(2):166-172.

42. Bernstein C, Facista A, Nguyen H, et al. Cancer and age related colonic crypt deficiencies in cytochrome $c$ oxidase I. World J Gastrointest Oncol. 2010;2(12):429-442.

43. Holubec H, Payne CM, Bernstein H, et al. Assessment of apoptosis by immunohistochemical markers compared to cellular morphology in ex vivo-stressed colonic mucosa. J Histochem Cytochem. 2005; 53(2):229-235.

44. Bernstein H, Payne CM, Kunke K, et al. A proteomic study of resistance to deoxycholate-induced apoptosis. Carcinogenesis. 2004;25(5): 681-692.

45. Payne CM, Waltmire CN, Crowley C, et al. Caspase-6 mediated cleavage of guanylate cyclase $\alpha 1$ during deoxycholate-induced apoptosis: Protective role of the nitric oxide signaling module. Cell Biol Toxicol. 2003;19(6):373-392.

46. Dall'Agnol M, Bernstein C, Bernstein H, Garewal H, Payne CM. Identification of S- nitrosylated proteins after chronic exposure of colonic epithelial cells to deoxycholate. Proteomics. 2006;6(5):1654-1662.

47. Schreck R, Rieber P, Baeuerle PA. Reactive oxygen intermediates as apparently widely used messengers in the activation of the NF-kappaB transcription factor and HIV-1. EMBO J. 1991;10(8):2247-2258.

48. Turpaev KT. Reactive oxygen species and regulation of gene expression. Biochem (Mosc). 2002;67(3):281-292.

49. Olofsson BA, Kelly CM, Kim J, Hornsby SM, Azizkhan-Clifford J. Phosphorylation of SP1 in response to DNA damage by ataxia telangiectasia-mutated kinase. Mol Cancer Res. 2007;5(12):1319-1330.

50. Iwahori S, Yasui Y, Kudoh A, et al. Identification of phosphorylation sites on transcription factor Sp1 in response to DNA damage and its accumulation at damaged sites. Cell Signal. 2008;20(10):1795-1803.

51. Zou Z, Gao C, Nagaich AK, et al. p53 regulates the expression of the tumor suppressor gene maspin. J Biol Chem. 2000;275(9): 6051-6054.

52. Talos F, Moll UM. Role of the $\mathrm{p} 53$ family in stabilizing the genome and preventing polyploidization. Adv Exp Med Biol. 2010;676:73-91

53. Yoshida K, Miki. The cell death machinery governed by the $\mathrm{p} 53$ tumor suppressor in response to DNA damage. Cancer Sci. 2010; 101(4): 831-835.

54. Maekawa T, Sano Y, Shinagawa T, et al. ATF-2 controls transcription of Maspin and GADD45 alpha genes independently from p53 to suppress mammary tumors. Oncogene. 2008;27(8):1045-1054.

55. Bowen C, Gelmann EP. NKX3.1 activates cellular response to DNA damage. Cancer Res. 2010;70(8):3089-3097.

56. Khalkhali-Ellis Z. Maspin: the new frontier. Clin Cancer Res. 2006;12(24):7279-7283.

57. Gao F, Shi HY, Daughty C, Cella N, Zhang M. Maspin plays an essential role in early embryonic development. Development. 2004;131(7):1479-1489.

58. Nelson DA, Tan T-T, Rabson AB, Anderson D, Degenhardt K, White E. Hypoxia and defective apoptosis drive genomic instability and tumorigenesis. Genes Dev. 2004;18(17):2095-2107.

59. Mendez O, Fernandez Y, Peinado MA, Moreno V, Sierra A. Antiapoptotic proteins induce non-random genetic alterations that result in selecting breast cancer metastatic cells. Clin Exp Metastasis. 2005; 22(4):297-307.

60. Law RH, Irving JA, Buckle AM, et al. The high resolution crystal structure of the human tumor suppressor maspin reveals a novel conformational switch in the G-helix. J Biol Chem. 2005;280:22356-22364.
61. Nawata S, Shi HY, Sugino N, Zhang M. Evidence of post-translational modification of the tumor suppressor maspin under oxidative stress. Int J Mol Med. 2011;27(2):249-254.

62. Cumming RC, Andon NL, Haynes PA, Park M, Fischer WH, Schubert D. Protein disulfide bond formation in the cytoplasm during oxidative stress. J Biol Chem. 2004;279(21):21749-21758.

63. Sheng S. Maspin and the order of signaling. Cancer Biol Ther. 2003; 2(4):404-405.

64. Nam E, Park C. Maspin suppresses survival of lung cancer cells through modulation of Akt pathway. Cancer Res Treat. 2010;42(1):42-47.

65. Pop C, Salvesen GS. Human caspases: Activation, specificity, and regulation. J Biol Chem. 2009;284(33):21777-21781.

66. Yin S, Li X, Meng Y, et al. Tumor-suppressive maspin regulates cell response to oxidative stress by direct interaction with glutathione S-tranferase. J Biol Chem. 2005;280(41):34985-34996.

67. Nobuoka A, Takayama T, Miyanishi K, et al. Glutathione-S-transferase P1-1 protects aberrant crypt foci from apoptosis induced by deoxycholic acid. Gastroenterol. 2004;127(2):428-443.

68. Ravagnan L, Gurbuxani S, Susin SA, et al. Heat-shock protein 70 antagonizes apoptosis-inducing factor. Nat Cell Biol. 2001;3(9):839-843.

69. Gurbuxani S, Schmitt E, Cande C, et al. Heat shock protein 70 binding inhibits the nuclear import of apoptosis-inducing factor. Oncogene. 2003;22(43):6669-6678.

70. Matsumori Y, Hong SM, Aoyama K, et al. HSP70 overexpression sequesters AIF and reduces neonatal hypoxic/ischemic brain injury. J Cereb Blood Flow Metab. 2005;25(7):899-910.

71. Lui JC, Kong SK. Heat shock protein 70 inhibits the nuclear import of apoptosis-inducing factor to avoid DNA fragmentation in TF-1 cells during erythropoiesis. FEBS Lett. 2007;581(1):109-117.

72. Zhu Q, Xu YM, Wang LF, et al. Heat shock protein 70 silencing enhances apoptosis inducing factor-mediated cell death in hepatocellular carcinoma HepG2 cells. Cancer Biol Ther. 2009;8(9):792-798.

73. Choudhury S, Bae, Ke Q, Lee JY, Kim J, Kang PM. Mitochondria to nucleus translocation of AIF in mice lacking Hsp70 during ischemia/ reperfusion. Basic Res Cardiol. 2011;106(3):397-407.

74. Ye H, Cande C, Stephanou NC, et al. DNA binding is required for the apoptogenic actin of apoptosis inducing factor. Nat Struct Biol. 2002;9(9):680-684.

75. Vahsen N, Cande C, Dupaigne P, et al. Physical interaction of apoptosis-inducing factor with DNA and RNA. Oncogene. 2006;25(12): $1763-1774$

76. Susin SA, Lorenzo HK, Zamzami N, et al. Molecular characterization of mitochondrial apoptosis-inducing factor. Nature. 1999;397(6718):441-446.

77. Modjtahedi N, Giordanetto F, Madeo F, Kroemer G. Apoptosis-inducing factor: vital and lethal. Trends Cell Biol. 2006;16(5):264-272.

78. Bernstein C, Bernstein H, Payne CM, Dvorak K, Garewal H. Field defects in progression to gastrointestinal tract cancers. Cancer Lett. 2009;260(1-2):1-10.

79. Nguyen H, Loustaunau C, Facista A, et al. Deficient Pms2, ERCC1, $\mathrm{Ku} 86, \mathrm{CcOI}$ in field defects during progression to colon cancer. J Vis Exp. July 28, 2010;(41). Pii: 1931. doi: 10.3791/1931.

80. Bernstein C, Holubec H, Bhattacharyya AK, et al. Carcinogenicity of deoxycholate, a secondary bile acid. Arch Toxicol. 2011;85(8): 863-871.

81. Payne CM, Holubec H, Bhattacharyya AK, Bernstein C, Bernstein H. Exposure of mouse colon to dietary bile acid supplement induces sessile adenomas. Inflamm Bowel Dis. 2009;16(5):729-730.

82. Blandamura S, D'Alessandro E, Guzzardo V, et al. Maspin expression in adenocarcinomas of the ampulla of Vater: relation with clinicopathological parameters and apoptosis. Anticancer Res. 2007;27(2):1059-1066.

83. Rana SS, Bhasin DK, Singh K. Ampulla of Vater as seen on capsule endoscopy. Gastrointest Endoscopy. 2008;68(3):613.

84. Washo-Stultz D, Hoglen N, Bernstein H, Bernstein C, Payne CM. Role of nitric oxide and peroxynitrite in bile salt-induced apoptosis: relevance to colon carcinogenesis. Nutr Cancer. 1999;35(2):180-188. 
85. Washo-Stultz D, Crowley-Weber CL, Dvorakova K, et al. Role of mitochondrial complexes I and II, reactive oxygen species and arachidonic acid metabolism in deoxycholate-induced apoptosis. Cancer Lett. 2002;177(2):129-144.

86. Bernstein H, Holubec H, Bernstein C, et al. Deoxycholate-induced colitis is markedly attenuated in Nos2 knock-out mice in association with modulation of gene expression profiles. Dig Dis Sci. 2007; 52(3):628-642.

87. Payne CM, Weber C, Crowley-Skillicorn C, et al. Deoxycholate induces mitochondrial oxidative stress and activates NF- $\kappa B$ through multiple mechanisms in HCT-116 colon epithelial cells. Carcinogenesis. 2007; 28(1):215-222.

88. Payne CM, Crowley C, Washo-Stultz D, et al. The stress-response proteins poly(ADP-ribose) polymerase and NF- $\kappa B$ protect against bile salt-induced apoptosis. Cell Death Diff. 1998;5(7):623-636.
89. Bernstein H, Payne C, Bernstein C, Beard S, Schneider J, Crowley C. Activation of the promoters of genes associated with DNA damage, oxidative stress, ER stress and protein malfolding by the bile salt, deoxycholate. Toxicol Lett. 1999;108(1):37-46.

90. Glinghammar B, Inoue H, Rafter JJ. Deoxycholic acid causes DNA damage in colonic cells with subsequent induction of caspases, COX-2 promoter activity and the transcription factors NF- $\mathrm{KB}$ and AP-1. Carcinogenesis. 2002;23(5):839-845.

91. Terzic J, Grivennikov S, Karin E, Karin M. Inflammation and colon cancer. Gastroenterol. 2010;138(6):2101-2114.

92. Kawanishi S, Hiraku Y. Oxidative and nitrative DNA damage as biomarker for carcinogenesis with special reference to inflammation. Antioxidants Redox Signal. 2006;8(5-6):1047-1058.

\section{Publish your work in this journal}

Clinical and Experimental Gastroenterology is an international, peerreviewed, open access journal, publishing all aspects of gastroenterology in the clinic and laboratory, including: Pathology, pathophysiology of gastrointestinal disease; Investigation and treatment of gastointestinal disease; Pharmacology of drugs used in the alimentary tract;
Immunology/genetics/genomics related to gastrointestinal disease. This journal is indexed on CAS. The manuscript management system is completely online and includes a very quick and fair peer-review system. Visit http://www.dovepress.com/testimonials.php to read real quotes from published authors.

Submit your manuscript here: http://www.dovepress.com/clinical-and-experimental-gastroenterology-journal 